\title{
References
}

\section{BOOKS AND OTHER MATERIALS}

1886 - Berne Convention Centenary - 1986: 1886 - Berne Convention Centenary - 1986: The Berne Convention for the Protection of Literary and Artistic Works from 1886 to 1986, 1986, WIPO Publication No. 877E.

Abbott 2009: Abbott, Frederick M. (2009), Cross-Retaliation in TRIPS: Options for Developing Countries, International Centre for Trade and Sustainable Development (ICTSD), Issue Paper No. 8, ICTSD, Switzerland.

Adeney 2006: Adeney, Elizabeth (2006), The Moral Rights of Authors and Performers, An International and Comparative Analysis, Oxford: Oxford University Press.

ALAI 2010 Report: Report of the ALAI Ad Hoc Committee on the Proposals to Introduce Mandatory Exceptions for the Visually Impaired, adopted by the Executive Committee of ALAI, Paris, 27 February 2010, available at http://www.alai.org/en/assets/files/ resolutions/report-mandatory-exceptions.pdf (accessed 23 January 2014).

Band 2013: Band, Jonathan (2013), A User Guide to the Marrakesh Treaty, Library Copyright Alliance, 6 August 2013, available at http:// www.librarycopyrightalliance.org/bm doc/user-guide-marrakesh-treaty1013final.pdf, accessed 23 January 2014.

Blakeney 2012: Blakeney, Michael (2012), Intellectual Property Enforcement - A Commentary on the Anti-Counterfeiting Trade Agreement (ACTA), Cheltenham, UK and Northampton, MA, USA: Edward Elgar. Blomqvist 2009: Blomqvist Jørgen (2009), Reflections on Article 15(4) of the Berne Convention, Emlékkönyv Ficsor Mihály 70. születésnapja, Hungary: Barátaitól, 54-63.

Blomqvist 2011: Blomqvist, Jørgen (2011), The Consistency of Mandatory Exceptions Treaties with International Conventions in the Field of Copyright and Related Rights, paper presented at the 2011 ALAI Congress in Dublin, available at http://www.alaidublin2011.org/wpcontent/uploads/2011/08/Jorgen-Blomqvist.pdf, (accessed 23 January 2014). 
Boas 2012: Boas, Gideon (2012), Public International Law, Contemporary Principles and Perspectives, Cheltenham, UK and Northampton, MA, USA: Edward Elgar.

Bogsch 1968: Bogsch, Arpad (1968), The Law of Copyright under the Universal Convention (3rd edn), Leiden and New Providence, NJ, USA: A W Sijthoff/R R Bowker Co.

Cavalli 1986: Cavalli, Jean (1986), La genèse de la Convention de Berne pour la protection des auvres littéraires et artistiques du 9 september 1886, Lausanne: Université de Lausanne - Faculté de droit.

Correa 2007: Correa, Carlos M. (2007): Trade Related Aspects of Intellectual Property Rights, A Commentary on the TRIPS Agreement, Oxford Commentaries on International Law, Oxford Commentaries on the GATT/WTO Agreements, 2007, Oxford: Oxford University Press.

Davies and Garnett (2010): Davies, Gillian and Kevin Garnett (2010): Moral Rights, London: Sweet \& Maxwell/Thomson Reuters.

European Max Planck Group on Conflict of Laws in Intellectual Property 2013: Conflict of Laws in Intellectual Property, The CLIP Principles and Commentary, (2013), Oxford: Oxford University Press.

Evans (ed.) 2010: Evans, Malcolm D. (ed.) (2010), International Law, (3rd edn), Oxford: Oxford University Press.

Fawcett and Torremans 2011: Fawcett, James C. and Paul Torremans (2011) Intellectual Property and Private International Law (2nd edn), Oxford: Oxford University Press.

Ficsor 2002: Ficsor, Mihály (2002), The Law of Copyright and the Internet. The 1996 WIPO Treaties, their Interpretation and Implementation, Oxford: Oxford University Press.

Ficsor 2004: Ficsor, Mihály (2004), Guide to the Copyright and Related Rights Treaties Administered by WIPO and Glossary of Copyright and Related Rights Terms, WIPO publication 891(E).

Ficsor 2012: Ficsor, Mihály (2012), Beijing Treaty on Audiovisual Performances (BTAP): first assessment of the third WIPO 'Internet Treaty', available at http://www.copyrightseesaw.net/archive/?sw_10_ item=24 (accessed 23 January 2014).

Ficsor 2013: Ficsor, Mihály (2013), Commentary to the Marrakesh Treaty on Accessible Format Copies for the Visually Impaired, available at http://www.copyrightseesaw.net/archive/?sw_10_item=50 (accessed 23 January 2014).

Final Report of the Ad Hoc Working Group on US Adherence to the Berne Convention (1985-1986) 10 Colum-VLA JL. \& Arts 513-18.

General Comment No. 17 (2005): United Nations Economic and Social Council, Committee on Economic Social and Cultural Rights, Thirtyfifth session, Geneva 7-25 November 2005, General Comment No. 17 (2005) The right of everyone to benefit from the protection of the moral 
and material interests resulting from any scientific, literary or artistic production of which he or she is the author, Document E/C.12/GC/17. Gervais 2012: Gervais, Daniel (2012), The TRIPS Agreement, Drafting History and Analysis (4th edn), London: Sweet \& Maxwell/Thomson Reuters.

Ginsburg and Lucas 2003: Ginsburg, Jane C. and André Lucas (2003), Rights of Performers to Producers of Audiovisual Fixations - Multilateral Instruments; United States of America; France, WIPOdocument AVP/IM/03/4 of 30 April 2003.

Ginsburg and Lucas 2004: Ginsburg, Jane C. and André Lucas (2004): Study on Transfer of the Rights of Performers to Producers of Audiovisual Fixations - Conclusion, WIPO-document AVP/IM/03/4 ADD of 12 May 2004.

Goldstein and Hugenholz 2013: Goldstein, Paul and Bernt Hugenholtz (2013), International Copyright (3rd edn), Oxford: Oxford University Press.

Implications 1996: Implications of the TRIPS Agreement on Treaties Administered by WIPO, WIPO publication 464(E), 1996.

von Lewinski 2008: von Lewinski, Silke (2008), International Copyright Law and Policy, Oxford: Oxford University Press.

Masouyé 1978: Masouyé, Claude (1978), Guide to the Berne Convention, WIPO publication 615(E), 1978, Switzerland.

Masouyé 1981: Masouyé, Claude (1981), Guide to the Rome Convention and to the Phonograms Convention, WIPO publication 617(E), 1981, Switzerland.

Nordemann, Vinck, Hertin and Meyer 1990: Nordemann, Wilhelm, Kai Vink and Paul W. Hertin (1990), International Copyright and Neighboring Rights Law, Commentary with special emphasis on the European Community, English Version by Dr. Gerald Meyer based on the translation of R. Livingston, Weinheim: VCH Verlagsgesellschaft.

Records Berlin: Actes de la conference réunie à Berlin du 14 october au 14 novembre 1908 avec les actes de ratification (1910), Bureau de l'Union internationale littéraire et artistique, Switzerland.

Records Berne 1884: Actes de la Conférence international pour la protection des cuvres littéraires et artistiques réunie à Berne du 8 au 19 septembre 1884 (1884), Bureau de l'Union internationale pour la protection des œuvres littéraires et artistiques, Switzerland.

Records Brussels: Documents de la Conférance réunie à Bruxelles du 5 au 26 juin 1948 (1951), Bureau de l'union internationale pour la protection des oeuvres littéraires et artistiques, Switzerland.

Records Rome 1928: Actes de la conférence réunie à Rome du 7 mai au 2 juin 1928 (1929), Bureau de l'Union internationale pour la protection des œuvres littéraires et artistiques, Switzerland. 
Records Rome 1961: Records of the Diplomatic Conference on the International Protection of Performers, Producers of Phonograms and Broadcasting Organizations, Rome, 10 to 26 October 1961 (1968), ILO, UNESCO, BIRPI.

Records Stockholm: Records of the Intellectual Property Conference of Stockholm (1967) (1971), WIPO, Switzerland.

Records Genève 1971: Records of the International Conference of States on the Protection of Phonograms 1971 (1975), UNESCO, WIPO.

Records Genève 1996: Records of the Diplomatic Conference on Certain Copyright and Neighboring Rights Questions, Geneva 1996, WIPO publication 348(E) (1999), Switzerland.

Reinbothe and von Lewinski 2002: Reinbothe, Jörg and Silke von Lewinski (2002), The WIPO Treaties 1996, the WIPO Copyright Treaty and the WIPO Performances and Phonograms Treaty, Commentary and Legal Analysis, London: LexisNexis Butterworths.

Ricketson 1986: Ricketson, Sam (1986), The Berne Convention for the Protection of Literary and Artistic Works: 1886-1986, London: Kluwer Law International.

Ricketson 2003: Ricketson, Sam (2003), WIPO Study on Limitations and Exceptions of Copyright and Related Rights in the Digital Environment, WIPO document SCCR/9/7, 2003, WIPO, Switzerland.

Ricketson and Ginsburg 2006: Ricketson, Sam and Jane C. Ginsburg (2005), International Copyright and Related Rights, The Berne Convention and Beyond (2nd edn), Oxford: Oxford University Press.

Senftleben 2004: Senftleben, Martin (2004), Copyright, Limitations and the Three-Step Test, An Analysis of the Three-Step Test in International and EC Copyright Law, Alphen aan den Rijn: Kluwer Law International.

Sterling 2008: Sterling, J.A.L. (2008), World Copyright Law (3rd edn), London: Sweet \& Maxwell/Thomson Reuters.

United Nations Conference on Trade and Development: Most-FavouredNation Treatment, UNCTAD Series on issues in international investment agreements, UNCTAD/ITE/IIT/10 (Vol III), 1999, United States of America and Switzerland: United Nations.

Wallace and Martin-Ortega 2010: Wallace, Rebecca M.M. and Olga Martin-Ortega (2010), International Law (6th edn), London: Sweet \& Maxwell/Thomson Reuters.

WIPO Intellectual Property Handbook: Policy, Law and Use (2004), Switzerland (online publication available at www.wipo.int).

WIPO Committee of Experts on Model Provisions for Legislation in the Field of Copyright, First Session, Geneva, February 20 to March 3, 1989, Draft Model Provisions for Legislation in the Field of Copyright, WIPO document CE/MPC/I/2-II, 1988, Switzerland. 
WIPO/UNESCO Second Committee of Governmental Experts on Copyright Problems Arising from the Use of Computers for Access to or the Creation of Works, (Paris, 7 to 11 June 1982), Report (1982), 18 Copyright - Monthly Review of the World Intellectual Property Organization (WIPO) 239-47.

\section{JOURNAL ARTICLES}

Austin, Graeme W. (1999), 'Domestic Laws and Foreign Rights: Choice of Law in Transnational Copyright Infringement Ligitation', 23 ColumVLA J L \& Arts 1-48.

Country of Origin Study Group of the International Literary and Artistic Association (ALAI) (2012): 'Determination of Country of Origin when a Work is First Publicly Disclosed over the Internet', 232 RIDA 2-43.

Davies, Gillian (2012), 'The 50th Anniversary of the Rome Convention for the Protection of Performers, Producers of Phonograms and Broadcasting Organizations: Reflections on the Background and Importance of the Convention', 2 QMJIP 206-24.

Dubin, Joseph S. (1954), 'The Universal Copyright Convention', 42 Cal L Rev 89-119.

Edelman, Bernard (1992), 'Applicable Legislation Regarding Exploitation of Colourized US Films in France: The "John Huston" Case', IIC 629-42.

Fabiani, Mario (1998), 'Copyright and Direct Broadcasting by Satellite', Copyright 17-26.

Ferney, Roger (1971), 'Paris 1971 or the Adventures of a Package Deal', 70 RIDA $1-45$.

Ficsor, Mihály (2002), 'How Much of What? The "Three-Step Test" and its Application in Two Recent WTO Dispute Settlement Cases', 192 RIDA 110-251.

Geiger, Christophe, Jonathan Griffiths and Reto M. Hilty (2008), 'Declaration on a Balanced Interpretation of the "Three-Step Test" in Copyright Law', 30(12) EIPR 489-99.

Geller, Paul Edward (1988-1989), 'Copyright Protection in the Berne Union: Analyzing the Issues', 13 Colum-VLA J L \& Arts 435-76.

Gervais, Daniel (2011), 'Golan v. Holder: A Look at the Constraints Imposed by the Berne Convention', 64 VNLRENB 147-63.

Ginsburg, Jane (2005), 'Legal Protection of Technological Protection Measures Protecting Works of Authorship: International Obligations and the US Experience', 29 Colum J L \& Arts 11-37. 
Ginsburg, Jane and Pierre Sirinelli (1991), 'Authors and Exploitations in International Private Law: The French Supreme Court and the Huston Film Colorization Controversy', 15 Colum-VLA J L \& Arts 135-59.

Katzenberger, Paul (1973), 'Wechsel der Anknüpfungspunkte im deutschen und internationalen Urheberrecht', GRUR Int 274-80.

von Lewinski, Silke (2001), 'International Protection for Audiovisual Performers: A Never-Ending Story? A Resumé of the WIPO Diplomatic Conference 2000', 189 RIDA 3-65.

von Lewinski, Silke (2002-2003), 'International Copyright over the last 50 Years - A Foreign Perspective', 50 J Copyright USA 581-607.

von Lewinski, Silke (2012), 'The Beijing Treaty on Audiovisual Performances', 6 Auteurs \& Media 539-46.

Oman, Ralph (1988), 'The United States and the Berne Union: An Extended Courtship', 3 J L \& Tech 71-119.

Peukert, Alexander (2004), 'Protection of Authors and Performing Artists in International Law - Considering the Example of Claims for Equitable Remuneration under German and Italian Copyright Law', 35(8) IIC 900-22.

Porcin, Adriane (2012), 'Of Guilds and Men: Copyright Workarounds in the Cinematographic Industry’, 35 Hastings Comm \& Ent L J 1-34.

Reinbothe, Jörg (1992), 'Der Schutz des Urheberrechts und der Leistungsschutzrechte im Abkommensentwurf GATT/TRIPs', GRUR Int 707-15.

Ricketson, Sam (1998-1999), 'The Shadowland of Berne: A Survey of the Hidden Parts of the Berne Convention', Part I: 7 EIPR 197-202, Part II: 8 EIPR 267-74 and Part III: 2 EIPR 58-65.

Ruse-Khan, Henning Grosse and Annette Kur (2011), 'Enough is Enough - The Notion of Binding Ceilings in International Intellectual Property Protection', in Annette Kur with Marianne Levin (eds), Intellectual Property Rights in a Fair World Trade System, Proposals for Reform of TRIPS, Cheltenham UK and Northampton, MA, USA: Edward Elgar, 359-407.

Ulmer, Eugen (1962-1963), 'The Rome Convention for the Protection of Performers, Producers of Phonograms and Broadcasting Organizations', Parts I, II and III, 10 Bull Copyright Soc'y USA 90-101, 165-178 and 219-48.

Vaver, David (1986), 'The National Treatment Requirements of the Berne and Universal Copyright Conventions', Part One: IIC 577-607; Part Two: IIC 715-33.

Xalabarder, Rachel (2002), 'Copyright: Choice of Law and Jurisdiction in the Digital Age', 8 Ann Surv Int'l \& Comp L 79-96. 
Jørgen Blomqvist - 9781783470976 Downloaded from PubFactory at 04/26/2023 02:57:10PM via free access 